Journal of Organometallic Chemistry, 172 (1979) 377-383

(C) Elsevier Sequoia S.A., Lausanne - Printed in The Netherlands

\title{
STABILIZATION OF ORGANOSILVER(I) COMPOUNDS, AND THEIR APPLICATION IN ORGANIC SYNTHESIS
}

H. WESTMIJZE, H. KLEIJN and P. VERMEER

Department of Organic Chemistry, State University of Utrecht, Croesestraat 79, Utrecht (The Netherlands)

(Received January 8th, 1979)

\section{Summary}

The favourable influence of lithium bromide on the thermal stability of organosilver(I) compounds is described. The stabilized silver(I) compounds have been brought into reaction with conjugated enynes; the regiochemistry of the reactions appears to depend on steric factors. A comparison is presented of the behaviour of the silver(I) and the corresponding copper(I) reagents in this reaction.

\section{Introduction}

The synthetic use of organocopper(I) compounds is well known [1-4] but the corresponding use of silver(I) compounds has received little attention. This is mainly because of the low thermal stability of many silver(I) compounds, especially of alkylsilver(I) [5-6]. Methylsilver(I), for instance, is stable only for a few seconds at $-30^{\circ} \mathrm{C}$, while the stability of alkylsilver(I) decreases still further with increasing chain length of the alkyl group so that a fast decomposition of n-propylsilver(I) occurs even at $-60^{\circ} \mathrm{C}$ [5]. On the other hand, $\mathrm{Ag}\left(\mathrm{CH}_{2}\right)_{3} \mathrm{NMe}_{2}$ is stable up to $+15^{\circ} \mathrm{C}$. The thermal stability of this compound has been attributed to an intramolecular complexation [7].

For synthetic applications of organosilver(I) compounds an improvement of the thermal stability of the reagents is a first requisite. In this paper we report a method of stabilizing organosilver(I) compounds, and show that the latter are useful tools in organic synthesis.

Results and discussion

(a) Improvement of the thermal stability of organosilver(I) compounds When we allowed silver(I) bromide to react with one or two mol equivalents of a Grignard reagent $(\mathrm{RMgX} ; \mathrm{R}=\mathrm{Bu}$ or $\mathrm{t}-\mathrm{Bu})$ in tetrahydrofuran (THF) at 
$-60^{\circ} \mathrm{C}$, the fast decomposition of the initially formed alkylsilver(I) compounds took place, with formation of black precipitates. The thermal decomposition of alkylsilver(I) compounds was effectively suppressed, however, when instead of silver(I) bromide the soluble complex $\mathrm{Ag}^{\mathrm{I}} \mathrm{Br} \cdot 2 \mathrm{LiBr}$ was used. For instance careful addition of $\mathrm{BuMgCl}$ to a solution of an equimolar amount of this complex in hexamethylphosphoric triamide (HMPT) * containing THF at $-60^{\circ} \mathrm{C}$ gave a light yellow homogeneous solution of BuAg $* *$, which appeared to be stable up to $-10^{\circ} \mathrm{C}$. The homogencous solution of the homoargentate $\mathrm{Bu}_{2} \mathrm{AgMgCl}$ prepared from $\mathrm{AgBr} \cdot 2 \mathrm{LiBr}$ and two molar equivalents of $\mathrm{BuMgCl}$ was colourless at $-60^{\circ} \mathrm{C}$. In this case darkening of the solution was observed at about $0^{\circ} \mathrm{C}$. Even t-BuAg (colour of the solution: light-brown) and $t-\mathrm{Bu}_{2} \mathrm{AgMgCl}$ (colour of the solution: light-yellow) prepared under the same conditions as the n-butyl analogs were stable at $-60^{\circ} \mathrm{C}$ in THF/HMPT. Darkening of the $\mathrm{t}-\mathrm{Bu}_{2} \mathrm{AgMgCl}$ solution was observed at about $-40^{\circ} \mathrm{C}$ while the t-BuAg solution showed visible decomposition at $-20^{\circ} \mathrm{C}$. At the moment it is difficult to rationalize the favourable influence of lithium bromide on the thermal stability of alkylsilver(I) compounds.

By analogy with copper(I) bromide incorporation into some arylcopper(I) cluster compounds to give more thermally stable clusters [8-9], we assume that lithium bromide is built into the alkylsilver(I) clusters. It is noteworthy that Semerano and Riccoboni observed a stabilizing influence of silver nitrate on methylsilver(I), but the effect was much less pronounced than in our case [10].

\section{(b) Addition of stabilized organosilver $(I)$ compounds to conjugated enynes}

In a recent paper [11] we reported on the cis-addition of organocopper(I) reagents to the triple bond in conjugated enynes. In order to investigate the synthetic utility of organosilver(I) compounds stabilized by lithium bromide we carried out a similar study with the latter reagents. For our study we chose three conjugated enynes, viz. 1-butenyne (I: $\left.R^{1}=H\right)$, 2-methyl-1-butenyne $\left(\mathrm{I}: \mathrm{R}^{1}=\mathrm{Me}\right.$ ) and 1-ethynylcyclohexene (X). The results obtained with enynes I are compiled in Table 1 , while the reaction of organosilver(I) compounds with $\mathrm{X}$ is discussed at the end of this section. Table 1 shows that $\mathrm{RAg} \cdot 2 \mathrm{LiBr}$ and $\mathrm{R}_{2} \mathrm{AgMgCl} \cdot 2 \mathrm{LiBr}(\mathrm{R}=\mathrm{Bu}$, i-Pr and $\mathrm{t}-\mathrm{Bu})$ were able to convert $\mathrm{I}$ into adducts for which we propose the structures III and IV (see Scheme 1; a propargylic structure $(=\mathrm{C}(\mathrm{Ag}$ or $\mathrm{AgR}) \mathrm{C} \equiv \mathrm{CH})$ and a $\pi$-allyl structure are also in principle possible). Protolysis of III and IV afforded the terminal allenes II in both cases. Generally, excess of I was required for a reasonable conversion of the silver(I) compounds. Under the same reaction conditions methyl- and phenyl-silver(I) reagents failed to react with $\mathrm{I}$.

Based on the yields of II as formed via the route I $\rightarrow$ IV $\rightarrow$ II, it can be concluded that under the conditions of the reaction the mixed argentate IV was not able to transfer the remaining $R$ group to the compounds I (Table 1 ,

* The presence of HMPT seems not to be essential but we used it as a co-solvent throughout our present study because it facilitates the formation of a homogeneous solution of the complex $\mathrm{Ag}^{\mathrm{I}} \mathrm{Br} \cdot 2 \mathrm{LiBr}$ from $\mathrm{Ag}{ }^{\mathrm{I}} \mathrm{Br}$ and $\mathrm{LiBr}$.

** A heteroargentate structure, viz. [BuAgBr]MgCl, is in principle also possible. 
TABLE 1

\begin{tabular}{|c|c|c|c|c|c|c|}
\hline \multirow{3}{*}{ Entry } & \multicolumn{6}{|c|}{$+\left(\mathrm{RAg}\right.$ or $\left.\mathrm{R}_{2} \mathrm{AgMgCl}\right) \cdot 2 \mathrm{LiBr} \rightarrow[\mathrm{III}$ or IV] $\stackrel{\mathrm{H}}{\rightarrow}^{+}=\underbrace{}_{\substack{\mathbf{R}^{1} \\
(\mathrm{II})}}$} \\
\hline & \multirow[t]{2}{*}{ Silver(I) compound ${ }^{a}$} & \multirow[t]{2}{*}{$\mathbf{R}^{1}$ in $\mathbf{I}$} & \multirow{2}{*}{$\begin{array}{l}\text { Mol } \\
\text { equivalents } \\
\text { of I }\end{array}$} & \multicolumn{2}{|c|}{ Reactions conditions $b$} & \multirow{2}{*}{$\begin{array}{l}\text { Yield } \\
(\%)^{c, c} \\
\text { of II }\end{array}$} \\
\hline & & & & $\begin{array}{l}\text { Temperature } \\
\left({ }^{\circ} \mathrm{C}\right)\end{array}$ & $\begin{array}{l}\text { Time } \\
\text { (h) }\end{array}$ & \\
\hline $\mathbf{1}$ & BuAg & $\mathrm{Me}$ & 2 & -10 & $\mathbf{3}$ & 57 \\
\hline 2 & BuAg & $\mathrm{Me}$ & 2 & 0 & 6 & 90 \\
\hline 3 & $\mathrm{Bu}_{2} \mathrm{AgMgCl}$ & $\mathrm{Me}$ & $\overline{1}$ & +20 & 18 & 26 \\
\hline 4 & $\mathrm{Bu}_{2} \mathrm{AgMgCl}$ & Me & 4 & +20 & 18 & 80 \\
\hline 5 & I-PrAg & MIe & 2 & -10 & $\mathbf{3 . 5}$ & 70 \\
\hline 6 & i-PrAg & $\mathrm{Me}$ & 2 & 0 & 3 & 97 \\
\hline 7 & $\mathrm{i}-\mathrm{Pr}_{2} \mathrm{AgMgCl}$ & $\mathrm{Me}$ & 1 & -10 & 3 & 50 \\
\hline 8 & $\mathrm{i}-\mathrm{Pr}_{2} \mathrm{AgMgCl}$ & $\mathbf{M e}$ & 2 & -10 & $\mathbf{3}$ & 91 \\
\hline 9 & $\mathrm{t}-\mathrm{BuAg}$ & $\mathrm{Me}$ & 1 & -20 & $\mathbf{3}$ & 70 \\
\hline 10 & $t-B u A g$ & $\mathbf{M e}$ & 2 & -20 & 3 & 96 \\
\hline 11 & $\mathrm{t}-\mathrm{Bu}_{2} \mathrm{AgMgCl}$ & $\mathrm{Me}$ & $\overline{1}$ & -40 & 3 & 85 \\
\hline 12 & $t-\mathrm{Bu}_{2} \mathrm{AgMgCl}$ & $\mathrm{Me}$ & 2 & -40 & 3 & 85 \\
\hline 13 & n-BuAg & $\mathbf{H}$ & 2 & 0 & 5 & 58 \\
\hline 14 & $\mathrm{i}-\mathrm{Pr}_{2} \mathrm{AgMgCl}$ & $\mathbf{H}$ & 2 & -10 & 3 & 70 \\
\hline 15 & t-BuAg & $\mathbf{H}$ & 2 & -20 & $\mathbf{3}$ & 70 \\
\hline
\end{tabular}

a In all cases 2 mol equivalents of $\mathrm{LiBr}$ were present and due to the manner of preparation also stoechiometric amounts of MgCIBr. ${ }^{b}$ All reactions were carried out in a mixture of THF/HMPT (10/1 (v/v)).

$c$ Yields are calculated on the amount of silver(I) compound used. In the case of homoargentates yields refer to one $\mathrm{R}$ transfer to the enyze. ${ }^{d}$ In all cases small amounts $(3-10 \%)$ of the $1,3-d i e n e s(E)-\mathrm{H}_{2} \mathrm{C}=$ $\mathrm{CR}^{1} \mathrm{CH}=\mathrm{CHR}(\mathrm{V})$ were present too.

\section{SCHEME 1}

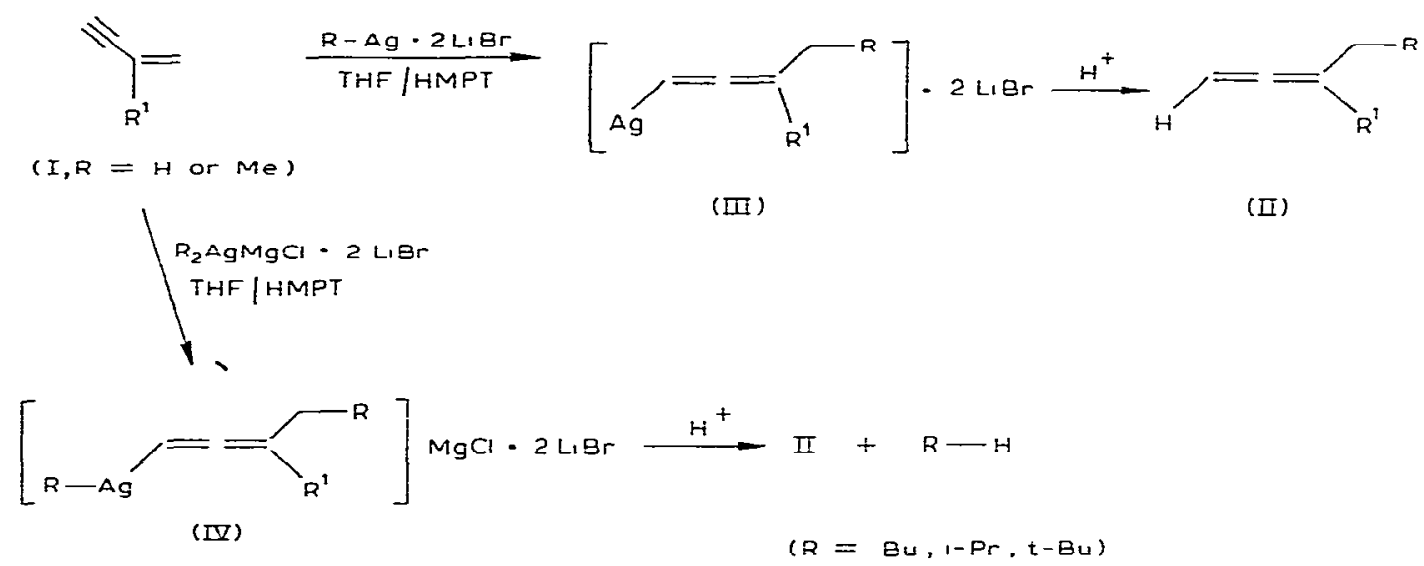

entries $3,4,7,8,11,12$ and 14). We observed the same phenomenon in the addition of organocuprates to 1-alkynylphosphines [12].

As indicated in Table 1, all the adducts II were contaminated with small amounts (3-10\%) of the 1,3 -dienes $(E)-\mathrm{H}_{2} \mathrm{C}=\mathrm{CR}^{2} \mathrm{CH}=\mathrm{CHR}$ (V, the $E$ configuration of the double bond was deduced from the ${ }^{1} \mathrm{H} N M R$ spectrum: ${ }^{3} J(\mathrm{HC}=\mathrm{CH})$ 
15-16 Hz). These 1,3-dienes resulted from a 1,2-addition of the silver(I) compounds to the triple bond in I (Scheme 2). From the $E$ geometry of V, it is cbvious that this addition took place in a cis manner *, a stereochemistry which is very common in organocopper(I) chemistry (see ref. 1-4).

SCHEME 2<smiles>C#CC(=C)C</smiles>

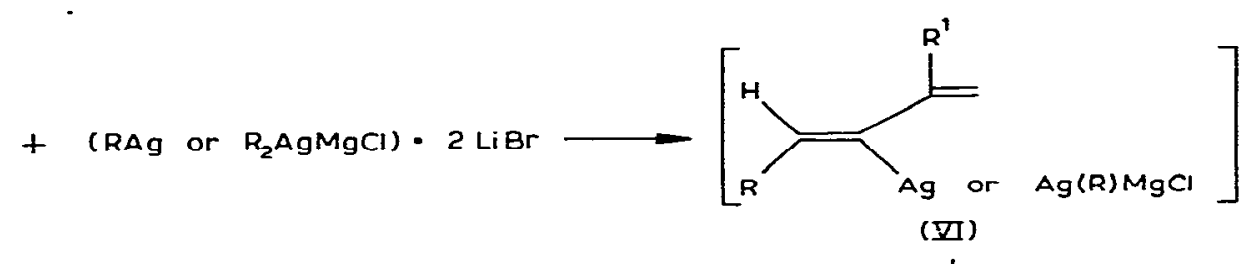

(I)

It can be concluded from our results that organosilver(I) reagents much prefer to transfer their $R$ group to the double bond in enynes $I$. This regioselectivity differs markedly from that reported by us for the addition of organocopper(I) reagents to enynes of type I [11], since the latter reagents convert enynes I mainly into the 1,3-dienes VII (see Scheme 3). Only with cuprates having bulky $\mathrm{R}$ groups were substantial amounts of the $(E)-1,3-$ dienes $\mathrm{V}$ also formed, but no addition to the double bond in $\mathrm{I}$ took place.

SCHEME 3
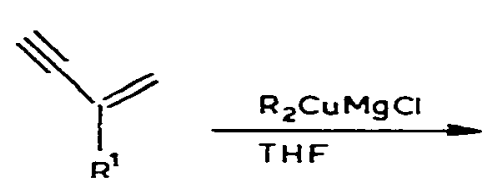

(I)

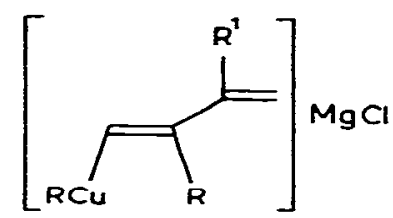

(VIII)<smiles>[R]C(=C)C([R])=C[IH+]C</smiles>

(DII)<smiles>[R]C=C(C=[R])C([R])CC</smiles>

(IX)

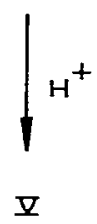

* We assume that protonolysis of $V I$ to give $V$ occurred with retention of configuration, as is normally observed with vinylcopper(I) compounds. 
Interestingly, we found that the reaction of the cuprate $\mathrm{t}-\mathrm{Bu}_{2} \mathrm{CuMgCl}$ with I did not follow the route given in Scheme 3 , but instead the route given for the argentate reaction in Schemes 1 and 2, producing a mixture of II and $\mathrm{V}$ on protonolysis $\left(\mathrm{R}^{\mathrm{I}}=\mathrm{H}: \mathrm{II} / \mathrm{V}>95 / 5\right.$, total yield of $\mathrm{II}+\mathrm{V}: 75 \% ; \mathrm{R}^{1}=\mathrm{Me}: \mathrm{II} / \mathrm{V}$ 95/5, total yield of II $+\mathrm{V}: 98 \%$ ). Yields refer to one t-Bu transfer from the cuprate). The reason why silver(I) reagents attack the double bond in $I$ and copper(I) reagents generally attack the triple bond is obscure.

Besides enynes $\mathrm{I}$ we also subjected 1-ethynylcyclohexene $\mathrm{X}$ to reactions with alkylsilver(I) compounds. The reactivity of alkylsilver(I) reagents towards this enyne appeared to be rather low, however, and it was not possible to obtain addition products from $\mathrm{X}$ and $\mathrm{Bu}_{2} \mathrm{AgMgCl} \cdot 2 \mathrm{LiBr}$ using the reaction conditions of entry 3 in Table 1 . A low conversion (33\%) of $X$ was obtained when $\mathrm{X}$ was treated with an equimolar amount of $\mathrm{t}-\mathrm{Bu} \mathrm{A}_{2} \mathrm{AgMgCl} \cdot 2 \mathrm{LiBr}$ for $3 \mathrm{~h}$ at $-40^{\circ} \mathrm{C}$ (compare entry 11 in Table 1 ). In the latter case the degree of conversion of $\mathrm{X}$ into adducts could be increased to $60 \%$ by allowing the reaction temperature to rise slowly to $+25^{\circ} \mathrm{C}$. Scheme 4 illustrates the results obtained with this enyne; the indicated yields refer to a transfer of one $R$ group from the argentate to $\mathrm{X}$.

SCHEME 4

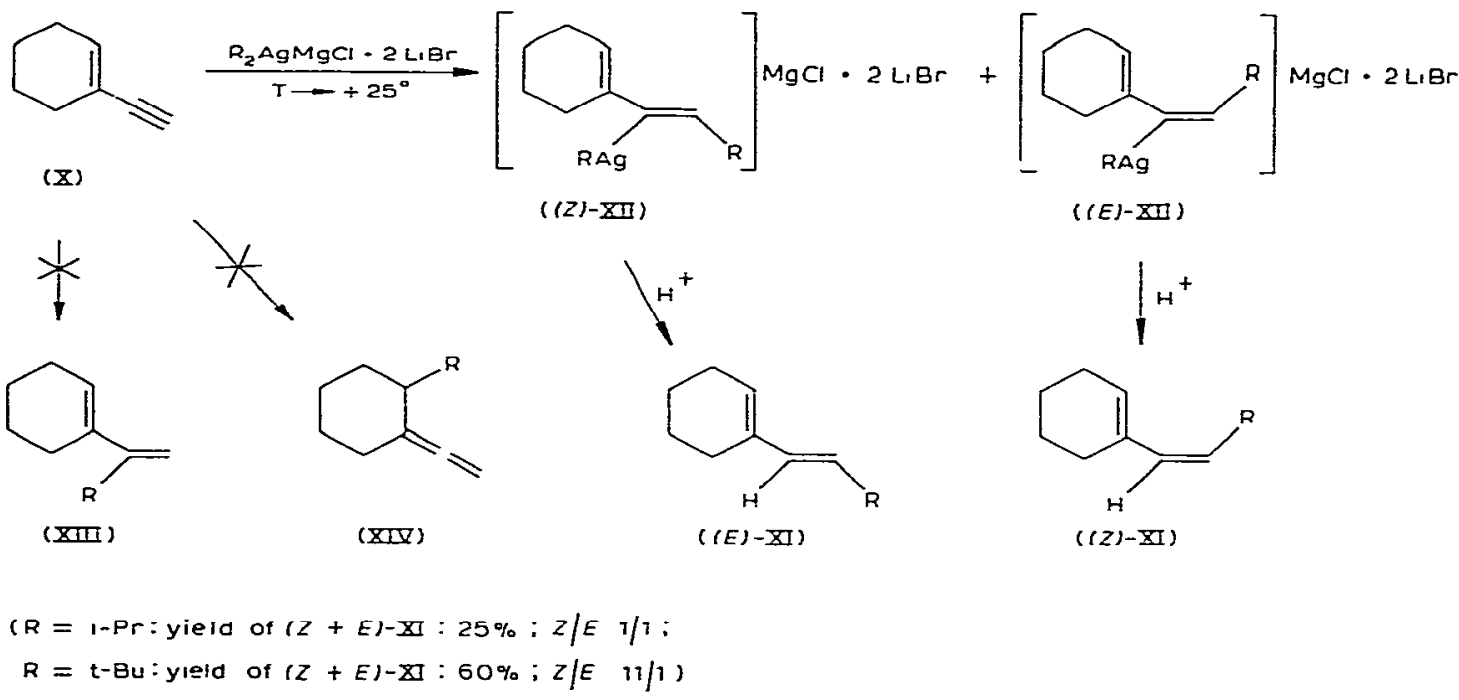

There are a number of interesting features in this case. First, the fact that the expected allene XIV was completely absent from the products points to a high susceptibility of the silver(I) reactions to steric factors. Secondly, comparison of the stereochemistry of the formation of the 1,3-diene V from I (see Scheme 2 ) with that of $(Z)$-XI from $X$ shows that the stereochemistry of the addition to the triple bond strongly depends on the type of the enyne used especially when $R$ is t-butyl. In contrast with the reactions of $\mathrm{i}-\mathrm{Pr}_{2} \mathrm{AgMgCl} \cdot 2 \mathrm{LiBr}$ and $\mathrm{t}-\mathrm{Bu}_{2} \mathrm{AgMgCl} \cdot 2 \mathrm{LiBr}$ we have found in the course of the present study that the corresponding cuprates react smoothly with $\mathrm{X}$ to give mixtures of the expected 1,3-dienes XIII and (E)-XI. (See Scheme 4 for the structures of these 1,3-dienes, see also Scheme 3 ). The ratio XIII/(E)-XI was 70/30 in both 
cases (yields of XIII $+(E)$-XI: $90 \%$ for $\mathrm{R}$ was $\mathrm{i}-\mathrm{Pr}$ and $85 \%$ for $\mathrm{R}$ was $\mathrm{t}$-Bu; the calculated yields refer to transfer of $R^{1}$ from the cuprate to $X$ ).

Conclusion

Alkylsilver(I) reagents stabilized with lithium bromide are useful reagents for the conversion of 1-butenyne and 2-methyl-1-butenyne into terminal allenes. In 1-ethynylcyclohexene the addition reaction is entirely at the triple bond, indicating that organosilver(I) reactions are very susceptible to steric factors. Since the results show that organosilver(I) reagents can behave very differently from the corresponding copper(I) compounds, further investigation of their synthetic applicability is desirable.

\section{Experimental}

All reactions were performed under dry nitrogen. The product mixtures were analysed by GLC (SE 33 column) and by ${ }^{1} \mathrm{H}$ NMR (Varian EM-390 spectrometer) and IR spectroscopy. The cuprate reactions were carried out as indicated in ref. 11.

(1) General procedure for the preparation of $R A g \cdot 2 \mathrm{LiBr}$.

To a stirred suspension of $\mathrm{Ag}^{\mathrm{I}} \mathrm{Br}(0.030 \mathrm{~mol})$ in THF (120 ml) we added a solution of lithium bromide $(0.060 \mathrm{~mol})$ in THF $(30 \mathrm{ml})$ followed by HMPT $(18 \mathrm{ml})$ at $+25^{\circ} \mathrm{C}$. The homogeneous solution was cooled to $-60^{\circ}$, and a solution of $\mathrm{RMgCl}(0.030 \mathrm{~mol})$ in THF $(30 \mathrm{ml})$ was added dropwise. The resulting homogeneous mixture was stirred for $20 \mathrm{~min}$ at $-60^{\circ} \mathrm{C}$.

(2) General procedure for the preparation of $\mathrm{R}_{2} \mathrm{AgMgCl} \cdot \mathrm{LiBr}$

The homoargentates $(0.030 \mathrm{~mol})$ were prepared from $\mathrm{Ag}^{\mathrm{I}} \mathrm{Br} \cdot 2 \mathrm{LiBr}(0.030$ $\mathrm{mol})$ and $\mathrm{RMgCl}(0.060 \mathrm{~mol})$ in a mixture of THF $(180 \mathrm{ml})$ and HMPT $(18 \mathrm{ml})$ following the procedure given under (1).

(3) Reaction of I with $\mathrm{RAg}-2 \mathrm{LiBr}$ and $\mathrm{R}_{2} \mathrm{AgMgCl} \cdot 2 \mathrm{LiBr}$

To a stirred solution of $\mathrm{RAg} \cdot 2 \mathrm{LiBr}(0.030 \mathrm{~mol})$ or $\mathrm{R}_{2} \mathrm{AgMgCl} \cdot 2 \mathrm{LiBr}$ $(0.030 \mathrm{~mol})$ in a mixture of THF $(180 \mathrm{ml})$ and HMPT $(18 \mathrm{ml})$ an appropriate amount (see Table 1 ) of enyne $I\left(R^{1}=H\right.$ or $\mathrm{Me}$ ) was added at $-60^{\circ} \mathrm{C}$. The temperature was allowed to rise during $15 \mathrm{~min}$ to the value indicated in Table 1 and, the mixture was stirred for several hours (see the Table) at this temperature. and added to a solution of ammonium chloride in water containing $\mathrm{NaCN}(2 \mathrm{~g})$. The products were isolated by extraction with pentane $(3 \times 50 \mathrm{ml})$. After washing the combined extracts with water $(5 \times 100 \mathrm{ml})$ and drying with $\mathrm{MgSO}_{4}$ the solvent was distilled off and the products were analysed. Physical constants and some spectroscopic data for the distilled compounds II are as follows:

Ocia-1,2-diene. B.p. $48-49^{\circ} \mathrm{C} / 39 \mathrm{mmHg} . n_{\mathrm{D}}^{20} 1.4400$. IR $(\mathrm{NaCl}) 1957$ ( $=\mathrm{C}=\mathrm{C}=\mathrm{C}=\mathrm{cm}^{-1} \cdot{ }^{1} \mathrm{H}-\mathrm{NMR}\left(\mathrm{CCl}_{4}, \mathrm{TMS}\right): \delta 5.00 \mathrm{ppm}(\mathrm{tt}, 1 \mathrm{H}, \mathrm{CH}=), \delta 4.57$ ppm (dt, $2 \mathrm{H}, \mathrm{H}_{2} \mathrm{C}=$ ).

5-Methyl-hexa-1,2-diene. B.p. $94-95^{\circ} \mathrm{C} / 760 \mathrm{mmHg} ; n_{\mathrm{D}}^{20} 1.4302$. IR $(\mathrm{NaCl})$ 1950 (二C $=\mathrm{C}=\mathrm{C}=) \mathrm{cm}^{-1} .{ }^{1} \mathrm{H} \mathrm{NMR}\left(\mathrm{CCl}_{4}, \mathrm{TMS}\right): \delta 5.00 \mathrm{ppm}(\mathrm{tt}, 1 \mathrm{H},-\mathrm{CH}=)$, $\delta 4.57 \mathrm{ppm}\left(\mathrm{dt}, 2 \mathrm{H}, \mathrm{H}_{2} \mathrm{C}=\right.$ ). 
3-Methylocta-1,2-diene. B.p. $60-61^{\circ} \mathrm{C} / 35 \mathrm{mmHg} ; n_{\mathrm{D}}^{22}$ 1.4405. IR $(\mathrm{NaCl})$ 1952 ( $=\mathrm{C}=\mathrm{C}=\mathrm{C}<$ ) $\mathrm{cm}^{-1} .{ }^{1} \mathrm{H}$ NMR $\left(\mathrm{CCl}_{4}, \mathrm{TMS}\right): \delta 4.52 \mathrm{ppm}\left(\mathrm{m}, 2 \mathrm{H}, \mathrm{H}_{2} \mathrm{C}=\right.$ ). 3,5-Dimethylhexa-1,2-diene. B.p. $38-39^{\circ} \mathrm{C} / 52 \mathrm{mmHg} ; n_{\mathrm{D}}^{21} 1.4350$. IR $(\mathrm{NaCl}) 1955\left(-\mathrm{C}=\mathrm{C}=\mathrm{C}-\mathrm{cm}^{-1} .{ }^{1} \mathrm{H} \mathrm{NMR}\left(\mathrm{CCl}_{4}, \mathrm{TMS}\right)=\delta 4.50 \mathrm{ppm}(\mathrm{m}, 2 \mathrm{H}\right.$, $\mathrm{H}_{2} \mathrm{C}=$ ).

3,5,5-Trimethylhexa-1,3-diene. B.p. $45-46^{\circ} \mathrm{C} / 30 \mathrm{mmHg} ; n_{\mathrm{D}}^{20} 1.4418$. IR $(\mathrm{NaCl}) 1948$ (二C=C=C二) $\mathrm{cm}^{-1} .{ }^{1} \mathrm{H} \mathrm{NMR}\left(\mathrm{CCl}_{4}, \mathrm{TMS}\right): \delta 4.52 \mathrm{ppm}(\mathrm{m}, 2 \mathrm{H}$, $\mathrm{H}_{2} \mathrm{C}=$ ).

\section{(4) Reaction of $X$ with $\mathrm{R}_{2} \mathrm{AgMgCl} \cdot 2 \mathrm{LiBr}$}

A mixture of the argentate $(0.030 \mathrm{~mol}, \mathrm{R}=\mathrm{i}-\mathrm{Pr}$ or $\mathrm{t}-\mathrm{Bu})$ and $\mathrm{X}(0.030 \mathrm{~mol})$ in HMPT $(18 \mathrm{ml})$ containing THF $(180 \mathrm{ml})$ was stirred for one hour at $-40^{\circ} \mathrm{C}$. The temperature was then allowed to rise to $+25^{\circ} \mathrm{C}$ during $1 \mathrm{~h}$. Stirring at $+25^{\circ} \mathrm{C}$ was continued for another hour. The mixture was worked up as indicated under (3). Scheme 4 shows the degree of conversion in these cases. The adduct obtained from $\mathrm{X}$ and $\mathrm{t}-\mathrm{Bu}_{2} \mathrm{AgMgCl} \cdot 2 \mathrm{LiBr}$ was separated from the starting enyne by distillation. B.p. $80^{\circ} \mathrm{C} / 20 \mathrm{mmHg}, n_{\mathrm{D}}^{20} 1.4742$, IR $(\mathrm{NaCl}) 735$ (CH=CH-t-Bu) cm ${ }^{-1},{ }^{1} \mathrm{H} \mathrm{NMR}$ ( $\left.\mathrm{CCl}_{4}, \mathrm{TMS}\right) \delta 5.60(\mathrm{~d}, 1 \mathrm{H}, \mathrm{CH}=\mathrm{C}-\mathrm{t}-\mathrm{Bu}), \delta 5.21$ $(\mathrm{d}, 1 \mathrm{H}, \mathrm{C}=\mathrm{CH}-\mathrm{t}-\mathrm{Bu}), \delta 1.08\left(\mathrm{~s}, 9 \mathrm{H},\left(\mathrm{CH}_{3}\right)_{3} \mathrm{C}\right) ;{ }^{3} \mathrm{~J}(\mathrm{HC}=\mathrm{CH})$ in the double bond $\mathrm{HC}=\mathrm{CH}-\mathrm{t}-\mathrm{Bu}: 12.2 \mathrm{~Hz}$.

\section{Acknowledgement}

This investigation was supported by the Netherlands Foundation for Chemical Research (S.O.N.).

\section{References}

1 J.F. Normant, Synthesis, (1972) 63.

2 G.H. Posner, Organic Reactions, 19 (1972) Chap. 1.

3 G.H. Posner, Organic Reactions, 22 (1975) Chap. 2.

4 A.E. Jukes, Advan. Organometal. Chem., 12 (1974) 215.

5 G. Bähr und P. Burba, Methoden zur Herstellung und Umwandlung von Organosilber-Verbindungen in E. MUller (Ed.). Houben-Weyl, Methoden der Organischen Chemie, Georg Thieme Verlag, Stuttgart, 1970, Band XIII/1, p. 763.

6 C.D.M. Beverwijk, G.J.M. van der Kerk, A.J. Leusink and J.G. Noltes, Organometal. Chem. Rev, A, 5 (1970) 215 .

7 H.K. Hofstee, Thesis, Univ. Utrecht, 1978.

8 G. van Koten, A.J. Leusink and J.G. Noltes, Inorg. Nucl. Chem. Lett., 7 (1977) 277.

9 J.M. Guss, R. Mason, K.M. Thomas, G. van Koten and J.G. Noltes, J. Organometal. Chem., 40 (1972) C79.

10 G. Semerano and R. Riccoboni, Ber., 74 (1941) 1089; see also: G. Coasta and A. Camus, Gazz. Chim. Ital., 86 (1956) 77; Chem. Abstr., 50 (1956) 12719.

11 H. Westmijze, H. Klein, J. Meijer and P. Vermeer, Tetrahedron Lett., (1977) 869; See also: F. Scott, G. Cahiez, J.F. Normant and J. Villieras, J. Organometal. Chem., 144 (1978) 13.

12 J. Meijer, H. Westmijze and P. Vermeer, Recl. Trav. Chim. Pays-Bas, 95 (1976) 102. 